I thank Dr. J. V. P'. Long for his advice and help, Dr. S. O. Agrell for supplying the specimens and Dr. G. F. Claringbull of the British Museum (Natural History) for supporting this work.

\section{S. J. B. REED *}

British Museum (Natural History), London.

* Present address: Department of Mineralogy and Petrology, University of Cambridge.

'Ringwood, A. E., Geochim. Cosmochim. Acta, 20, 155 (1960),

" Keil, K., J. Geophys. Res., 67, 4055 (1962).

${ }^{3}$ Ringwood. A. E., Geochim. Cosmochim. Acta, 24, 159 (1961).

- Prior, (;. T., and Hex, M. H., Catalogue of Meteorites (British Museum (Natural History), London, 1953).

"Agrell, S. ()., Long, J. V. P., and Ogilvie, R. E., Nature, 198, 749 (1963).

'Reed, S. J. B., Geochim. Cosmochim. Acta (in the press).

'Anders, E.. Space Sci. Revs. (in the press).

"Owen. E. A., and Liu, Y. H.. J. Iron and Steel In.st., 163, 13: (1949).

\section{CRYSTALLOGRAPHY}

\section{Crystal Structure of Lamprophyllite}

A specrmen of the mineral lamprophyllite (from Kola, the U.S.S.R.) at present being investigated is monoclinic, space group $C 2 / m$, with unit cell dimensions : $a=19 \cdot 76 \AA$, $b=7.06 \AA, c=5.40 \AA, \beta=96.5^{\circ}$. The unit cell formula is : $4 \times(\mathrm{Ba}, \mathrm{Sr}, \mathrm{K}) \mathrm{Na}(\mathrm{Ti}, \mathrm{Fe}) \mathrm{TiSi}_{2}(\mathrm{O}, \mathrm{OH}, \mathrm{F})_{9}$.

Using $174 h k 0$ reflexions, the structure has becn determined in projection along the $z$-axis. The atom positions found are given in Table 1 and the projection along the $z$-axis is shown in Fig. 1. The short repeat distance of the $z$-axis enables the main features of the structure in three dimensions to be determined unambiguously.

The structure is closely related to those of the minerals seidozerite $^{1}$, rosenbuschite ${ }^{2}$ and bafertisite ${ }^{3}$. The basic unit is an infinite sheet of cations, chiefly sodium and titanium, in octahedral co-ordination. To either side of this are attached sheets of silicon-oxygen tetrahedra and titanium-oxygen polyhedra arranged as shown in Fig. 2.

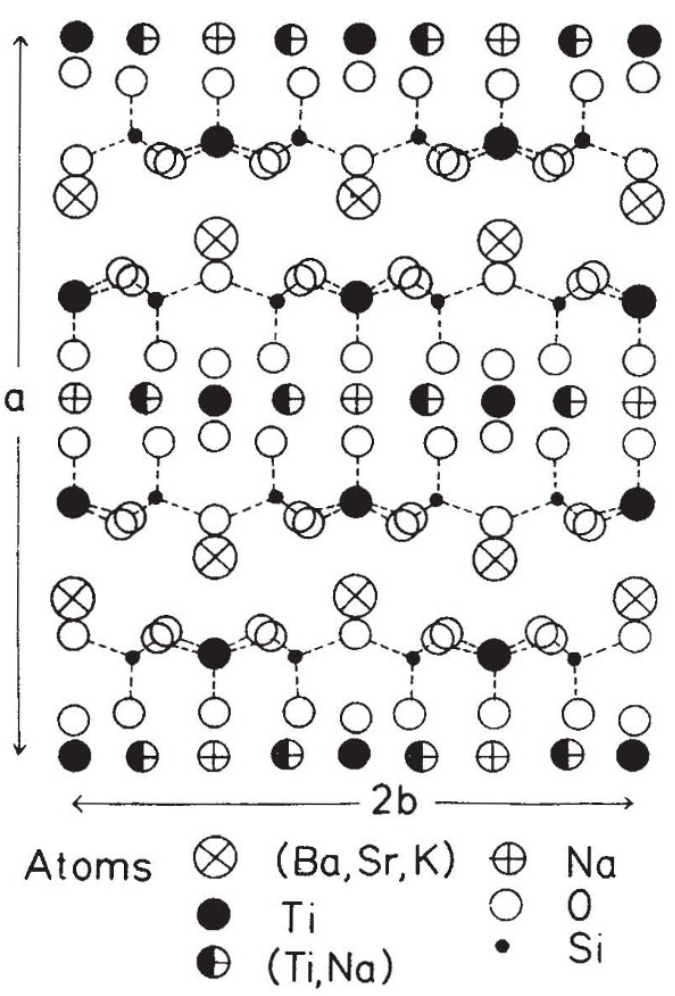

Fig. 1. Lamprophyllite projection along $z$-axis
Table 1. ATom Co-ORDinatris

$\begin{array}{ccc}\text { Atom } & x & y \\ \text { Ba, } \mathrm{Sr}, \mathrm{K}) & 0 \cdot 217 & 0 \cdot 000 \\ \mathrm{Si} & 0 \cdot 140 & 0 \cdot 217 \\ \mathrm{Ti} & 0 \cdot 000 & 0 \cdot 000 \\ \text { (Ti, } \mathrm{Na} \text { ) } & 0 \cdot 000 & 0 \cdot 239 \\ \mathrm{Na} & 0 \cdot 000 & 0 \cdot 500 \\ \mathrm{Ti} & 0 \cdot 146 & 0 \cdot 500 \\ O & 0 \cdot 056 & 0 \cdot 000 \\ 0 & 0 \cdot 059 & 0 \cdot 205 \\ 0 & 0 \cdot 062 & 0 \cdot 500 \\ O & 0 \cdot 165 & 0 \cdot 310 \\ O & 0.173 & 0 \cdot 312 \\ \mathrm{O} & 0 \cdot 174 & 0.000\end{array}$

These composite sheets are separated by barium atoms. The titanium-oxygen polyhedra shown in Fig. 2 are square pyramids, the titanium boing in five-fold co-ordination. In this respect lamprophyllite differs from the minerals mentioned above, in which the titanium, or zirconium in some cases, is in six-fold, octahedral. co-ordination.

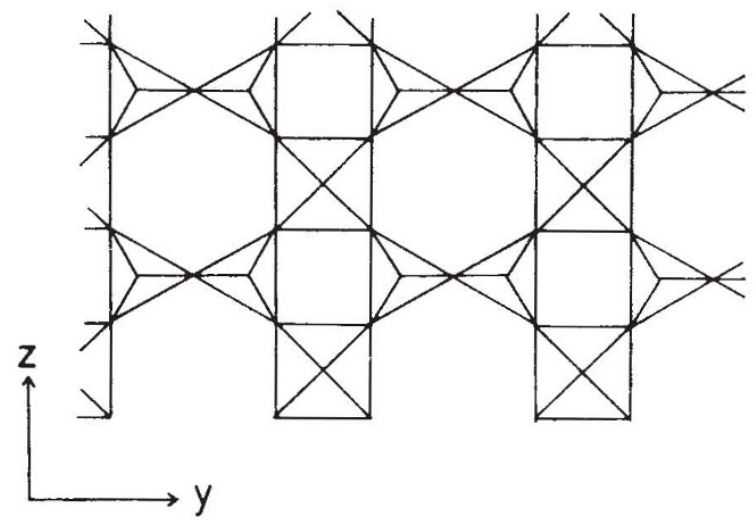

Fig. 2. Arrangement of SiO, and $\mathrm{TiO}_{j}$ polyhedra

Work is in progress to determine directly a second projection of the structure.

This work was supported by a Department of Scientific and Industrial Research research studentship.

Peter J. Woodrow

Department of Geology and Mineralogy,

University Museum, Oxford.

'Simonov, V. I., and Belov, N. V., Kristallografiya, 4, 163 (1959).

'2hibaeva, R. P., Simonov, V. I., and Belov, N. V., Kristallografiya, 8, .506 (1963).

${ }^{3}$ Simonov, V. 1., and Belov, N. V., Dokl. Akad. Nauk. S.S.S.R., 149, $1+16$ (1963).

\section{CHEMISTRY}

\section{Aluminium Oxyfluoride and the Polymerized Species in $\mathrm{AlOCI}$ Solutions}

Actrough the crystalline aluminium oxyhalides AlOCl, $\mathrm{AlOBr}$ and AlOI are known ${ }^{1-3}$, the corresponding A.lOF is not. We have tried to prepare $\mathrm{AlOF}$ by the procedure which is commonly used to prepare the other $\mathrm{AlOX}$ compounds, namely, the reaction of $3 \mathrm{AlF}_{3}$ with $\mathrm{As}_{2} \mathrm{O}_{3}$ in sealed evacuated glass ampoules at elevated temperatures. However, A.lOF was not formed at temperatures up to $480^{\circ} \mathrm{C}$, although reaction between $\mathrm{AlF}_{3}$ and $\mathrm{As}_{\mathrm{s}} \mathrm{O}_{3}$ did occur. Details of these experiments will be published elsewhere. Whereas A.IOCl can be prepared by the reaction of steam and $\mathrm{AlCl}_{3}$ (ref. 4), it does not appear that $\mathrm{AlOF}$ can be prepared by a comparable reaction with $\mathrm{AlF}_{3}$. Schober and Thilo ${ }^{5}$ found that $\mathrm{AlF}_{3}$ reacts with steam at temperatures up to $600^{\circ} \mathrm{C}$ to form a product with a $5 \cdot 2 \mathrm{per}$ cent fluorine content, and lower fluorine contents at higher temperatures. They formulated their product as $\mathrm{Al}_{7} \mathrm{O}_{10} \mathrm{~F}$. Locsei $^{6}$ obtained similar results but preferred to formulate the product as a mixture of $\mathrm{Al}_{2} \mathrm{O}_{3}$ and $\mathrm{AlOF}$. No reason 